\title{
Comparative Lipid Composition of Aerobically and Anaerobically Grown Desulfurolobus ambivalens, an Autotrophic Thermophilic Archaeobacterium
}

\author{
By A. TRINCONE, ${ }^{1}$ V. LANZOTTI, ${ }^{1} \dagger$ B. NICOLAUS,${ }^{1}$ W. ZILLIG,$^{2}$ \\ M. DE ROSA ${ }^{1,3}$ AND A. GAMBACORTA ${ }^{1 *}$ \\ ${ }^{1}$ Istituto per la Chimica di Molecole di Interesse Biologico del Consiglio Nazionale delle \\ Ricerche, Via Toiano 6, 80072-Arco Felice, Napoli, Italy \\ ${ }^{2}$ Max-Planck Institut für Biochemie, Martinsried, FRG \\ ${ }^{3}$ Istituto di Biochimica delle Macromolecole, I Facolta' di Medicina e Chirurgia dell'Universita', \\ Via Costantinopoli 16, 80138-Napoli, Italy
}

(Received 3 March 1989; revised 12 June 1989; accepted 26 June 1989)

Lipids from the autotrophic thermophilic archaeobacterium Desulfurolobus ambivalens grown under aerobic and anaerobic conditions were analysed and compared with those of Sulfolobus solfataricus, a related micro-organism. The ether lipids of aerobically and anaerobically grown $D$. ambivalens, as well as those of $S$. solfataricus, had the same general features except for the degree of cyclization of the $\mathrm{C}_{40}$ isopranic chains. The quinone content of $D$. ambivalens was strongly affected by growth conditions. Aerobically grown cells contained caldariellaquinone, 6-(3,7,11,15,19,23-hexamethyltetracosyl)-5-methylthiobenzo[b]thiophen-4,7-quinone $(83 \%$ of the quinone pool), sulfolobusquinone, 6-(3,7,11,15,19,23-hexamethyltetracosyl)-5-methylbenzo[b]thiophen-4,7-quinone $(16 \%)$ and the tricyclic quinone benzo[1,2-b; 4,5-b']dithiophen4,8 -quinone (trace amounts). In anaerobically grown $D$. ambivalens sulfolobusquinone was the only quinone present.

\section{INTRODUCTION}

Growth conditions of extreme $\mathrm{pH}$ and/or temperature and the information they provide on the evolution of life make the thermophiles the most interesting representatives of the archaeobacteria. All species grow anaerobically, and most require sulphur as an energy source. However, a few species can grow aerobically and not all of those that use sulphur require it as an energy source (Woese, 1987). Such thermophilic archaeobacteria have been assigned to the orders Sulfolobales and Thermoproteales (Stetter, 1986; Woese, 1987).

The genus Sulfolobus contains isolates that are respiratory heterotrophs capable of growth on a variety of carbon sources, or are facultative chemolithoautotrophs capable of obtaining their energy by the oxidation of sulphur to sulphuric acid or sulphide to molecular sulphur (Stetter, 1986).

Zillig et al. (1986) isolated a novel thermophilic sulphur-dependent archaeobacterium which can grow either aerobically as do Sulfolobus species by the oxidation of sulphur to sulphuric acid or anaerobically, like species belonging to the order Thermoproteales, by the reduction of sulphur to hydrogen sulphide. On the basis of its unique ability to grow facultatively via sulphur reduction, its immunochemical crossreactions and its $\mathrm{G}+\mathrm{C}$ content, the authors suggested the separation of the new isolate from the genus Sulfolobus and named it Desulfurolobus ambivalens (Zillig et al., 1986).

$\dagger$ Present address: Facolta' di Agraria, Universita' del Molise, Campobasso, Italy.

Abbreviations: GDGT(s), glycerol-dibisphytanyl-glycerol tetraether(s); GDNT(s), glycerol-dibisphytanylnonitol tetraether(s); GLI, glycolipid I; GLII, glycolipid II; SGLII, sulphoglycolipid II; PLI, phospholipid I; PGLI, phosphoglycolipid I; PGLII, phosphoglycolipid II; Glcp, glucopyranosyl; Galp, galactopyranosyl. 
The lipids of archaeobacteria are characterized by unusual structural features that can be considered as specific taxonomic markers (Langworthy, 1985; De Rosa \& Gambacorta, 1988). The complex lipids of archaeobacteria are mainly based on two classes of isopranoid ether core lipids that are characterized as diethers and tetraethers. The diethers are essentially based on glycerol, with a 2,3-sn configuration, linked to phytanyl, sesterterpanyl or head-to-head bisphytanyl chain(s). The second class contains macrocyclic tetraethers based on two head-tohead bisphytanyl $\omega$ - $\omega^{\prime}$ diols, linked via an ether linkage to two 2,3-sn-glycerol moieties (glycerol-dibisphytanyl-glycerol tetraether, GDGT) or to one 2,3-sn-glycerol and one branchedchain nonitol moiety (glycerol-dibisphytanyl-nonitol tetraether, GDNT). The aliphatic $\mathrm{C}_{40}$ chains may have as additional features up to four cyclopentane rings, the extent of cyclization of which varies according to species, and to growth conditions such as temperature, heterotrophy, autotrophy, etc. (De Rosa \& Gambacorta, 1988).

GDNT lipids are found only in members of the Sulfolobales and seem to be a specific taxonomic marker. The Sulfolobales display the widest lipid spectrum found in archaeobacteria at the level both of polar end structure and of isoprenic chain variety (De Rosa \& Gambacorta, 1988). On the basis of their quinone distribution thermophilic archaeobacteria can be divided into two groups: those with naphthoquinone isoprenoids and those with benzothiophenquinones (Collins \& Jones, 1981; Thurl et al., 1986; De Rosa \& Gambacorta, 1988). Species of the order Sulfolobales, whose quinones are all based on a benzothiophene nucleus, are unique to the second group. Thus, data on the distribution of the quinones, although still fragmentary, and data on the complex and core lipid patterns found in archaeobacteria, indicate that a correlation between classifications based on other criteria and that based on lipid distribution is possible.

This paper reports on the detailed analysis of lipid and quinone patterns in $D$. ambivalens grown either aerobically or anaerobically. These data are compared with those on lipids from Sulfolobus solfataricus to provide further information on the phylogenetic position of Desulfurolobus within the order Sulfolobales.

\section{METHODS}

Micro-organisms and culture conditions. Desulfurolobus ambivalens was isolated from solfataric sources in Iceland and at the Vulcano Island beach in Italy and from the Pisciarelli hot springs in Italy. Cells were grown in the standard medium described by Zillig et al. (1986). Anaerobic batch cultures were grown at $80^{\circ} \mathrm{C}, \mathrm{pH} 2.5$, in the presence of $1 \mathrm{~g}$ sulphur $\mathrm{l}^{-1}$ with continuous gassing with $80 \% \mathrm{CO}_{2} / 20 \% \mathrm{H}_{2}(\mathrm{v} / \mathrm{v})$. Aerobic batch cultures were grown under the same culture conditions as above in an atmosphere of air supplemented with $5 \%(\mathrm{v} / \mathrm{v}) \mathrm{CO}_{2}$.

Extraction and isolation of lipids. Dried cells (about $6 \mathrm{~g}$ ) were extracted (Soxhlet) first for $15 \mathrm{~h}$ with $\mathrm{CHCl}_{3} / \mathrm{CH}_{3} \mathrm{OH}(1: 1, \mathrm{v} / \mathrm{v})$ and then for $15 \mathrm{~h}$ with $\mathrm{CH}_{3} \mathrm{OH} / \mathrm{H}_{2} \mathrm{O}(1: 1, \mathrm{v} / \mathrm{v})$. The extracts were pooled and evaporated to give the total lipid residue of which $20 \%$ was directly hydrolysed to analyse the core lipid pattern. The remaining $80 \%$ of the lipid extract was treated with light petroleum (b.p. $40-70{ }^{\circ} \mathrm{C}$ ) and the soluble material chromatographed on a silica gel column (Merck Kieselgel 70-230 mesh, $20 \mathrm{~g})(20 \mathrm{~cm} \times 10 \mathrm{~mm}$, i.d.). The column was eluted with 11 of a step gradient of $0-15 \%(\mathrm{v} / \mathrm{v})$ diethyl ether in light petroleum in $5 \%$ increments $(250 \mathrm{ml}$ for each gradient step). The quinone fraction was eluted with $5 \%$ diethyl ether and further resolved by preparative HPLC.

The complex lipids that were insoluble in light petroleum were chromatographed on a silica gel (Merck Kieselgel 70-230 mesh, $60 \mathrm{~g})$ column $\left(40 \mathrm{~cm} \times 10 \mathrm{~mm}\right.$, i.d.). $\mathrm{CHCl}_{3} / \mathrm{CH}_{3} \mathrm{OH}(93: 7, \mathrm{v} / \mathrm{v})$ was used to elute the less polar compounds; $\mathrm{CHCl}_{3} / \mathrm{CH}_{3} \mathrm{OH}(8: 2, \mathrm{v} / \mathrm{v})$ eluted $\mathrm{GLI}$ and $\mathrm{GLII} ; \mathrm{CHCl}_{3} / \mathrm{CH}_{3} \mathrm{OH}(6: 4, \mathrm{v} / \mathrm{v})$ eluted PLI; $\mathrm{CHCl}_{3} / \mathrm{CH}_{3} \mathrm{OH} / \mathrm{H}_{2} \mathrm{O}\left(65: 25: 1\right.$, by vol.) gave SGLII; $\mathrm{CHCl}_{3} / \mathrm{CH}_{3} \mathrm{OH} / \mathrm{H}_{2} \mathrm{O}(65: 25: 4$, by vol.) gave a mixture of PGLI and PGLII.

The mixture of GLI and GLII was further resolved by preparative TLC, washed with $0 \cdot 1 \mathrm{M}$-boric acid and activated by heating at $100^{\circ} \mathrm{C}$ for $5 \mathrm{~h}$. After elution with $\mathrm{CHCl}_{3} / \mathrm{CH}_{3} \mathrm{OH} / \mathrm{H}_{2} \mathrm{O}(65: 25: 4$, by vol.), the glycolipids, located by $\mathrm{I}_{2}$ vapour, were scraped off and eluted with $\mathrm{CHCl}_{3} / \mathrm{CH}_{3} \mathrm{OH} / \mathrm{H}_{2} \mathrm{O}(65: 25: 4$, by vol.). The mixture of PGLI and PGLII was subjected to alkaline hydrolysis as reported previously (De Rosa et al., 1980). The resulting mixture of two glycolipids, GLI and GLII, were further resolved as described above.

GLI, GLII, PLI and SGLII, pure as shown by TLC analysis, were weighed to evaluate their relative percentages. The relative percentage of PGLI and PGLII was evaluated as glycolipid derivatives after alkaline hydrolysis. 
Identification of lipids was achieved by spectroscopic $\left({ }^{1} \mathrm{H}\right.$ and $\left.{ }^{13} \mathrm{C} \mathrm{NMR}\right)$, chromatographic and degradative methods as reported previously (De Rosa et al., 1980, 1983) using, for comparison, authentic lipids obtained from S. solfataricus.

Hydrolysis of lipids and purification of isopranoid ether components. Lipids were hydrolysed by heating with $2 \mathrm{M}-\mathrm{HCl}$ at $110^{\circ} \mathrm{C}$ in a stoppered reaction tube for $16 \mathrm{~h}$. After cooling, the reaction mixture was dried under vacuum and partitioned by addition of equal volumes of $\mathrm{CHCl}_{3}$ and $\mathrm{H}_{2} \mathrm{O}$. The chloroform-soluble fraction was chromatographed on a silica gel column (Merck Kieselgel 70-230 mesh, $20 \mathrm{~g})(20 \mathrm{~cm} \times 10 \mathrm{~mm}$, i.d.). $\mathrm{CHCl}_{3} /$ diethyl ether $(98: 2, \mathrm{v} / \mathrm{v})$ eluted 2,3-di-O-phytanyl-sn-glycerol; $\mathrm{CHCl}_{3} /$ diethyl ether $(9: 1$, v/v) eluted GDGTs; and $\mathrm{CHCl}_{3} / \mathrm{CH}_{3} \mathrm{OH}(95: 5, \mathrm{v} / \mathrm{v})$ eluted GDNTs. Purified compounds were weighed to estimate their relative percentages. The GDGTs and GDNTs, the latter as fully acetylated derivatives, were resolved into single differently cyclized components by HPLC. The relative proportion of each lipid was calculated by integration of peak areas on HPLC.

Isopranoid ether acetylation. GDNTs were acetylated with acetic anhydride/pyridine $(9: 1, \mathrm{v} / \mathrm{v})$ by refluxing for $6 \mathrm{~h}$. The reaction mixture was then dried under vacuum and analysed by HPLC.

Chromatographic procedures. TLC was done on $0.25 \mathrm{~mm}$ layers (analytical) and on $2 \mathrm{~mm}$ layers (preparative) of silica gel F 254 (Merck) activated by heating at $100^{\circ} \mathrm{C}$ for $2 \mathrm{~h}$. Solvents used were light petroleum/diethyl ether $(95: 5, \mathrm{v} / \mathrm{v})$ for the quinones; $\mathrm{CHCl}_{3} /$ diethyl ether $(95: 5, \mathrm{v} / \mathrm{v})$ for 2,3 -di-O-phytanyl-sn-glycerol; $\mathrm{CHCl}_{3} / \mathrm{diethyl}$ ether $(9: 1, \mathrm{v} / \mathrm{v})$ for GDGTs and fully acetylated GDNTs; $\mathrm{CHCl}_{3} / \mathrm{CH}_{3} \mathrm{OH}(9: 1, \mathrm{v} / \mathrm{v})$ for GDNTs; and $\mathrm{CHCl}_{3} / \mathrm{CH}_{3} \mathrm{OH} / \mathrm{H}_{2} \mathrm{O}\left(65: 25: 4\right.$, by vol.) for complex lipids. All compounds were detected either by exposure to $\mathrm{I}_{2}$ vapour or by spraying with $0 \cdot 1 \% \mathrm{Ce}\left(\mathrm{SO}_{4}\right)_{2}$ in $1 \mathrm{M}-\mathrm{H}_{2} \mathrm{SO}_{4}$. The Dittmer and Lester (Dittmer \& Lester, 1964) reagent was used for phospholipids and $\alpha$-naphthol/ $\mathrm{H}_{2} \mathrm{SO}_{4}$ for glycolipids.

HPLC analyses were done on a Waters apparatus equipped with a differential refractometer, using a

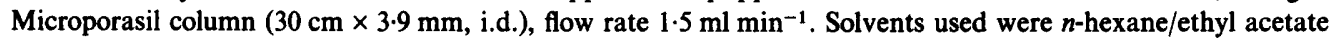
$(99: 1, v / v)$ for quinones, $n$-hexane/ethyl acetate $(85: 15, v / v)$ for GDGTs and $n$-hexane/ethyl acetate $(7: 3, v / v)$ for GDNT acetates.

\section{RESULTS AND DISCUSSION}

Total lipids from D. ambivalens grown aerobically and anaerobically accounted for about $8 \%$ of dried cells in both cases, a value very close to that of $S$. solfataricus (De Rosa et al., 1980).

The total quinone content as well as the type of quinone present in D. ambivalens seemed to be affected by growth conditions (Table 1). While the quinone fraction represented $0 \cdot 16 \%$ of cell dry wt in aerobically grown cultures, in the absence of oxygen the quinone content fell to only $0.05 \%$. A similar trend has been reported for facultative anaerobic micro-organisms in which the quinone content may depend to some extent on the extent of anaerobiosis and increases with increased oxygen tension (Brodie, 1965).

In aerobically grown cells caldariellaquinone (Fig. $1 a$ ) represented $83 \%$ of the quinone pool and sulfolobusquinone (Fig. 1 b) $16 \%$, while tricyclic quinone (Fig. 1c) was present in only trace amounts. In contrast, in anaerobically grown cells sulfolobusquinone was the only quinone present. Conflicting data have been provided by Thurl et al. (1986), showing that in anaerobically grown $D$. ambivalens equal amounts of both caldariellaquinone and sulfolobusquinone are present.

The complex lipid patterns of $D$. ambivalens (grown aerobically and anaerobically) closely resembled those of $S$. solfataricus, the same complex lipids being present in both genera. Moreover, the relative proportions of the different complex lipids were quite similar, with the exception of PGLI (Table 2).

The hydrolysis of total lipid extract of $D$. ambivalens gave rise to a mixture of GDGTs and GDNTs (Fig. 2, Table 3) and to trace amounts of 2,3-di-O-phytanyl-sn-glycerol. The relative ratios of GDGTs and GDNTs in $D$. ambivalens grown under different conditions and in $S$. solfataricus were comparable. In contrast, the cyclic composition of GDGT and GDNT fractions showed significant differences. In particular, D. ambivalens tetraethers were less cyclized and showed less structural variety when compared to those from $S$. solfataricus grown under standard conditions (De Rosa et al., 1980, 1989). In D. ambivalens the GDGT and GDNT composition was strongly affected by the presence or absence of oxygen during growth. In 


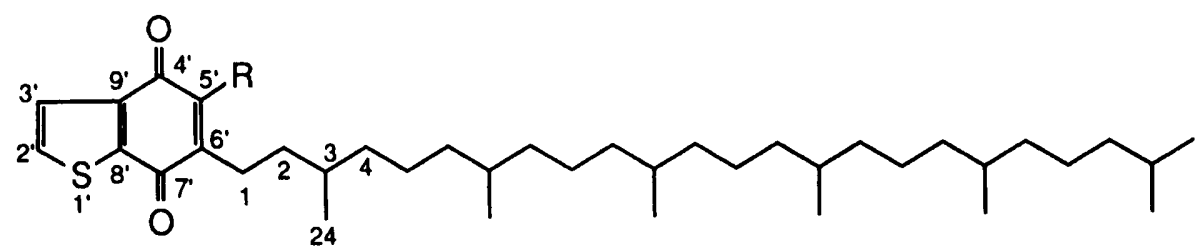

(a) $\mathrm{R}=\mathrm{SCH}_{3}$; caldariellaquinone

(b) $\mathrm{R}=\mathrm{CH}_{3}$; sulfolobusquinone

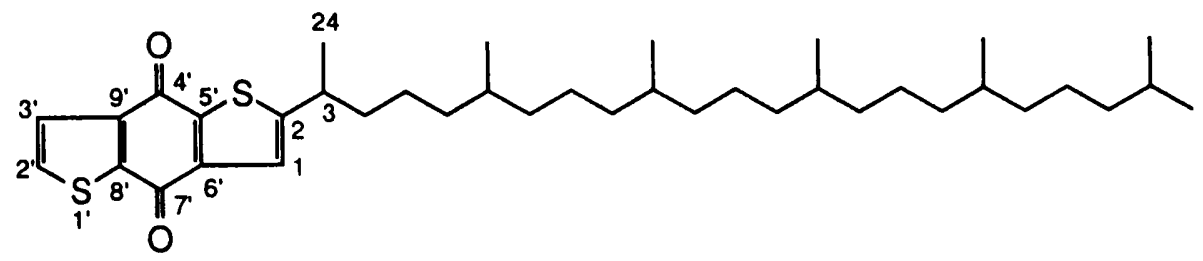

(c) Tricyclic quinone

Fig. 1. Chemical structures of benzothiophenquinones occurring in the order Sulfolobales.

Table 1. Quinone composition of D. ambivalens and S. solfataricus $\mathrm{CQ}$, caldariellaquinone; SQ, sulfolobusquinone; TQ, tricyclic quinone. (For structures see Fig. 1.)

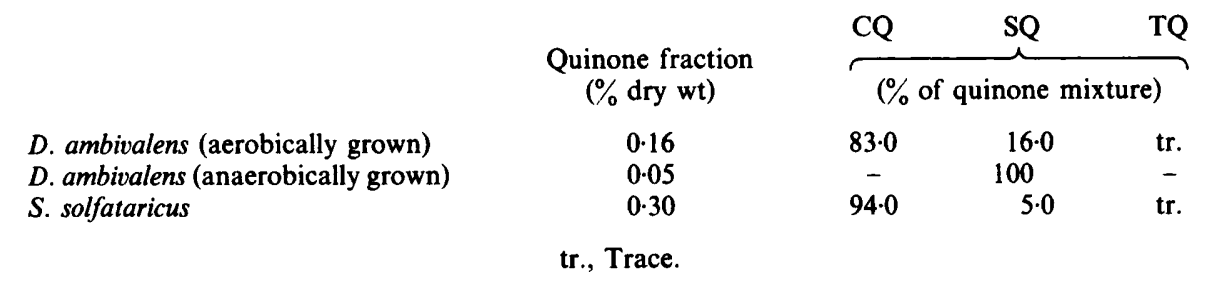

Table 2. Structures of major complex lipids and percentage lipid composition of D. ambivalens and $S$. solfataricus

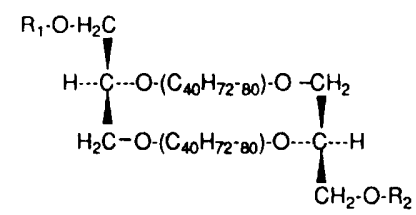

Compounds 1,2 and 3
Compound $\quad \mathbf{R}_{1} \quad \mathbf{R}_{2}$

1 GLI $\mathrm{H} \quad \beta$-D-Glc $p \rightarrow \beta$-D-Gal $p$

2 PLI Phosphoinositol $H$

3 PGLI Phosphoinositol $\beta$-D-Glc $p \rightarrow \beta$-D-Gal $p$

4 GLII H

5 SGLII H $\begin{array}{llll}5 & \text { SGLII } & \text { H } & \beta \text {-D-Glc } p \text {-sulphate } \\ 6 & \text { PGLII } & \text { Phosphoinositol } & \beta \text {-D-Glc } p\end{array}$

\section{$\beta$-D-Glc $p$}

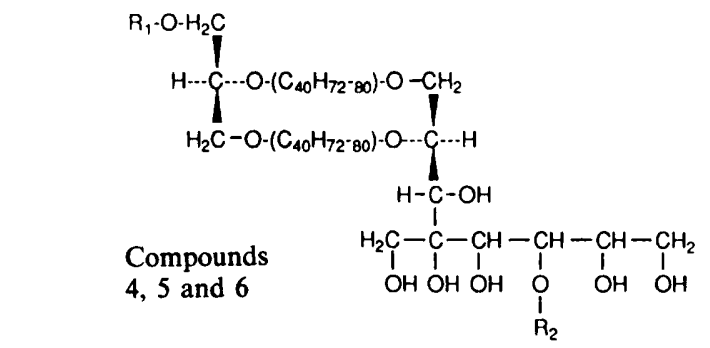
Lipid composition (\%)
D. ambivalens

$\overbrace{\text { Aerobically grown Anaerobically grown }} S$. solfataricus 
Table 3. Composition of the GDGT and GDNT fractions isolated from lipid hydrolysates of D. ambivalens and $S$. solfataricus

The GDNT/GDGT molar ratio was 2 for aerobically grown $D$. ambivalens and 3 for anaerobically grown $D$. ambivalens and for $S$. solfataricus.

\begin{tabular}{|c|c|c|c|}
\hline \multirow[b]{3}{*}{$\begin{array}{l}\text { No. of cyclopentanes } \\
\text { per molecule* }\end{array}$} & \multicolumn{3}{|c|}{ GDGT composition $(\%)$} \\
\hline & \multicolumn{2}{|c|}{ D. ambivalens } & \multirow[b]{2}{*}{ S. solfataricus } \\
\hline & $\begin{array}{l}\text { Aerobically } \\
\text { grown }\end{array}$ & $\begin{array}{l}\text { Anaerobically } \\
\text { grown }\end{array}$ & \\
\hline $\begin{array}{ll}0+0 & \text { (a) } \\
0+1 & \text { (f) } \\
1+1 & \text { (b) } \\
2+1 & \text { (g) } \\
2+2 & \text { (c) } \\
3+2 & \text { (h) } \\
3+3 & \text { (d) } \\
4+3 & \text { (i) } \\
4+4 & \text { (e) }\end{array}$ & $\begin{array}{r}6 \cdot 2 \\
10 \cdot 1 \\
16 \cdot 0 \\
28 \cdot 0 \\
35 \cdot 6 \\
4 \cdot 1 \\
- \\
- \\
-\end{array}$ & $\begin{array}{c}- \\
- \\
- \\
7 \cdot 0 \\
93 \cdot 0 \\
- \\
- \\
- \\
-\end{array}$ & $\begin{array}{r}1 \cdot 0 \\
1 \cdot 5 \\
3 \cdot 9 \\
13 \cdot 2 \\
26 \cdot 9 \\
25 \cdot 6 \\
17 \cdot 0 \\
6 \cdot 3 \\
4 \cdot 6\end{array}$ \\
\hline \multirow[t]{3}{*}{ Mean cyclization value $\dagger$} & $2 \cdot 9$ & 3.9 & $4 \cdot 7$ \\
\hline & \multicolumn{3}{|c|}{ GDNT composition $(\%)$} \\
\hline & \multicolumn{2}{|c|}{ D. ambivalens } & \\
\hline $\begin{array}{c}\text { No. of cyclopentanes } \\
\text { per molecule* }\end{array}$ & $\begin{array}{l}\text { Aerobically } \\
\text { grown }\end{array}$ & $\begin{array}{l}\text { Anaerobically } \\
\text { grown }\end{array}$ & S. solfataricus \\
\hline $\begin{array}{ll}0+0 & \left(\mathrm{a}^{\prime}\right) \\
0+1 & \left(\mathrm{f}^{\prime}\right) \\
1+1 & \left(\mathrm{~b}^{\prime}\right) \\
2+1 & \left(\mathrm{~g}^{\prime}\right) \\
2+2 & \left(\mathrm{c}^{\prime}\right) \\
3+2 & \left(\mathrm{~h}^{\prime}\right) \\
3+3 & \left(\mathrm{~d}^{\prime}\right) \\
4+3 & \left(\mathrm{i}^{\prime}\right) \\
4+4 & \left(\mathrm{e}^{\prime}\right)\end{array}$ & $\begin{array}{c}- \\
- \\
- \\
7 \cdot 0 \\
93 \cdot 0 \\
- \\
- \\
- \\
-\end{array}$ & $\begin{array}{r}- \\
- \\
- \\
100 \\
- \\
- \\
- \\
- \\
-\end{array}$ & $\begin{array}{r}0.5 \\
1.2 \\
1.8 \\
10 \cdot 2 \\
21 \cdot 8 \\
32 \cdot 2 \\
19 \cdot 6 \\
7.6 \\
5 \cdot 1\end{array}$ \\
\hline Mean cyclization value $\dagger$ & 3.9 & $3 \cdot 0$ & 4.9 \\
\hline
\end{tabular}

aerobic conditions, the main tetraethers present were $\mathrm{a}-\mathrm{c}, \mathrm{f}-\mathrm{h}, \mathrm{c}^{\prime}$ and $g^{\prime}$, whilst under anaerobic condition the tetraethers $\mathrm{c}, \mathrm{g}$ and $\mathrm{g}^{\prime}$ were the most representative core lipids (Fig. 2, Table 3). The degree of cyclization of GDGTs and GDNTs obtained by hydrolysis of each pure lipid was similar to that obtained by hydrolysis of total complex lipids.

The results reported in this paper show that the complex lipid composition of $D$. ambivalens, grown both aerobically and anaerobically, is very similar to that described for the genus Sulfolobus. Moreover, in D. ambivalens GDNTs and benzothiophenquinones, found until now only in the genus Sulfolobus, are also present. These similar lipid patterns, the presence of trehalose (Nicolaus et al., 1988) and the use of the same glucose catabolic pathway (data not published) by both Desulfurolobus and Sulfolobus confirm the close relationship between these two genera.

The authors thank Dr M. R. Vaccaro for her skilled assistance, Mrs I. Romano and Mr E. Pagnotta for technical assistance and $\mathrm{Mr} \mathrm{R}$. Turco for preparing the figures. 

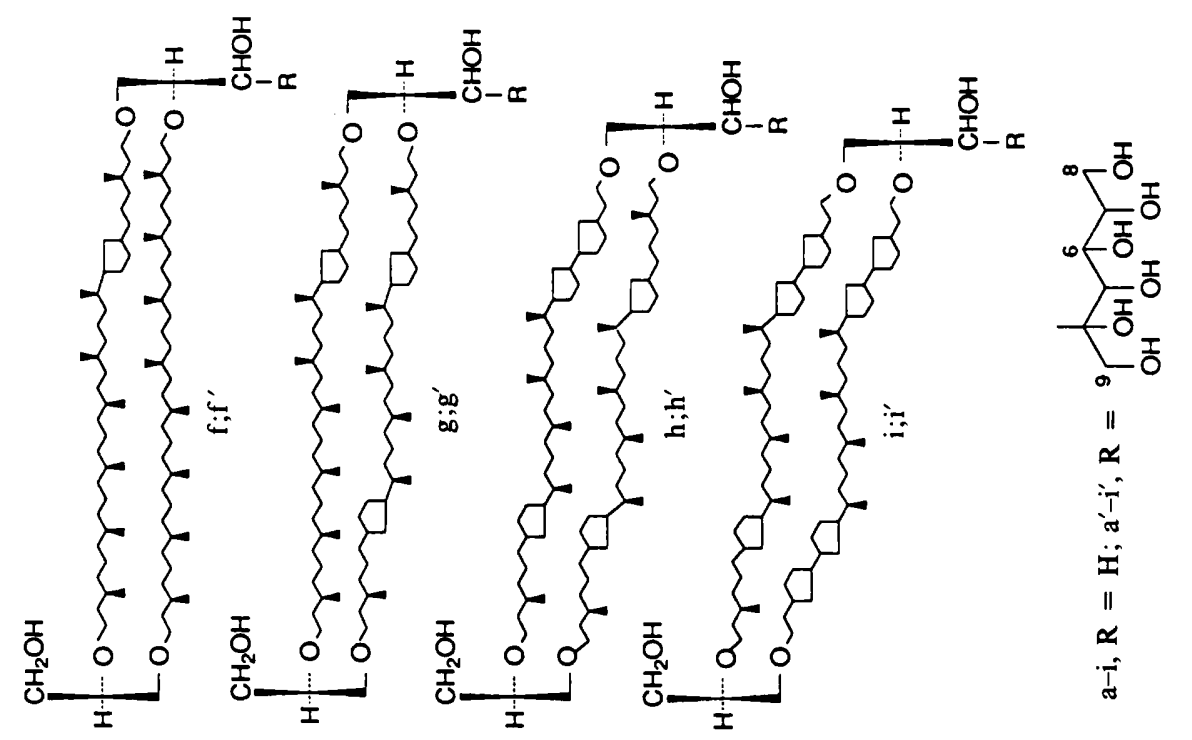

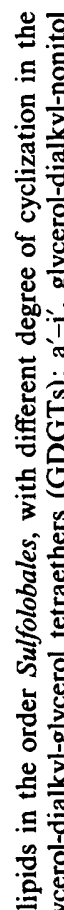

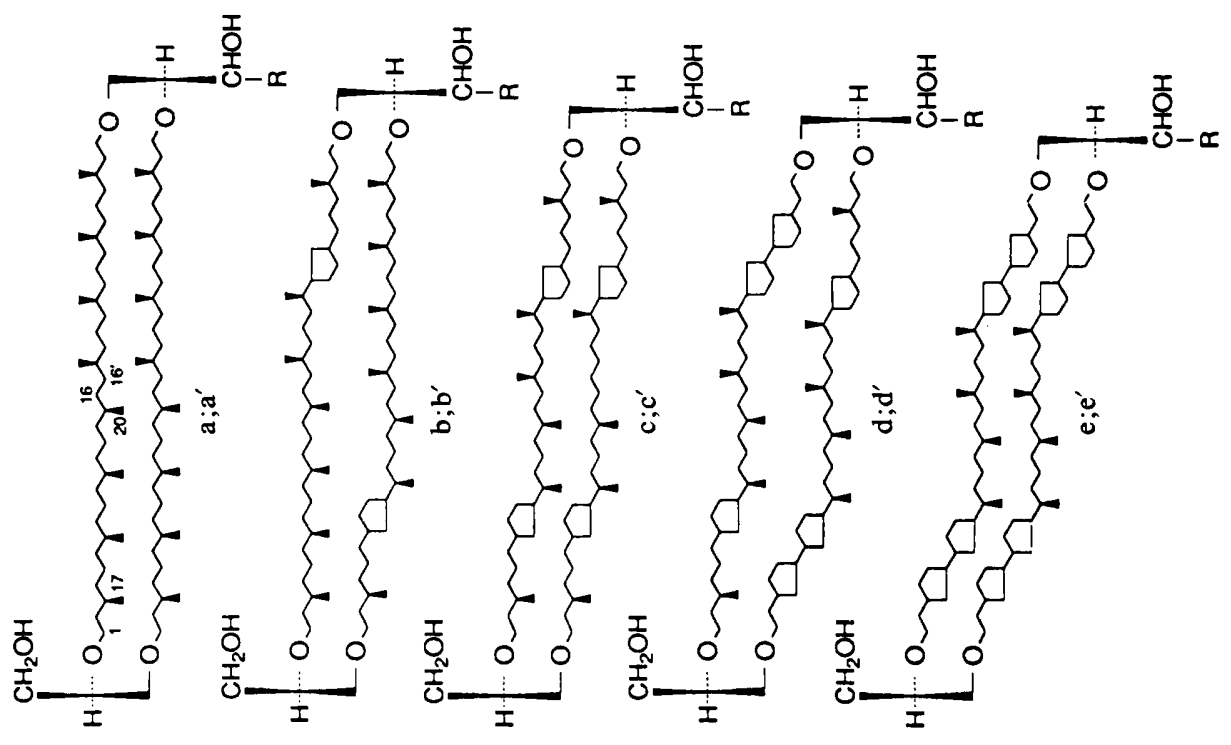




\section{REFERENCES}

Brodie, A. F. (1965). The role of naphthoquinones in oxidative metabolism. In Biochemistry of Quinones, pp. 359-360. Edited by R. A. Morton. London \& New York: Academic Press.

Collins, M. D. \& Jones, D. (1981). Distribution of isoprenoid quinone structural types in bacteria and their taxonomic implications. Microbiological Reviews 45, 316-354.

De Rosa, M. \& Gambacorta, A. (1988). The lipids of archaebacteria. Progress in Lipid Research 27, 153175.

De Rosa, M., Gambacorta, A., Nicolaus, B. \& Bu'Lock, J. (1980). Complex lipids of Caldariella acidophila, a thermoacidophile archaebacterium, based on bipolar ether lipids. Phytochemistry 9, 821825.

De Rosa, M., Gambacorta, A. \& Nicolaus, B. (1983). A new type of cell membrane, in thermophilic archaebacterium, based on bipolar ether lipids. Journal of Membrane Science 16, 287-294.

De Rosa, M., Lanzotti, V., Nicolaus, B., Trincone, A. \& Gambacorta, A. (1989). Lipids of archaebacteria: structural and biosynthetic aspects. In The Microbiology of Extreme Environments and its Biotechnology Potential. Amsterdam: Elsevier Applied Science Publishers (in the Press).
DitTMer, J. C. \& Lester, E. L. (1964). A simple, specific spray for the detection of phospholipids on thin layer chromatograms. Journal of Lipid Research 5, 126-127.

LANGWORTHY, T. D. (1985). Lipids of archaebacteria. In The Bacteria 8, pp. 459-497. Edited by C. R. Woese \& R. S. Wolfe. New York: Academic Press. Nicolaus, B., Gambacorta, A., Basso, A. L., Riccio, R., De Rosa, M. \& Grant, W. D. (1988). Trehalose in archaebacteria. Systematic Applied Microbiology 10, 215-217.

STETTER, K. O. (1986). Diversity of extremely thermophilic archaebacteria. In Thermophiles: General, Molecular and Applied Microbiology, pp. 39-74. Edited by T. D. Brock. New York: John Wiley.

ThURL, S., WITKe, W., BUHROW, I. \& SCHÄFER, W. (1986). Quinones from archaebacteria II. Biological Chemistry Hoppe Seyler 367, 191-198.

WoESE, C. R. (1987). Bacterial evolution. Microbiological Reviews 51, 221-271.

Zillig, W., Yeats, S., Holz, I., BoCK, A., RettenBERG, M., GropP, F. \& Simon, G. (1986). Desulfurolobus ambivalens, gen. nov., sp. nov., an autotrophic archaebacterium facultatively oxidizing or reducing sulfur. Systematic Applied Microbiology 8, 197-203. 